\title{
Pembelajaran Linguistik Arab di Program Studi Sastra Arab Fakultas Sastra UAI
}

\author{
Zaqiah Mardiah $^{1}$, Afridesy Puji Pancarani ${ }^{2}$, Dede Ridwanullah ${ }^{3}$ \\ 1,2,3Program Studi Sastra Arab, Fakultas Sastra, Universitas Al Azhar Indonesia, Jalan \\ Sisingamangaraja, Kebayoran Baru, Jakarta Selatan,12110 \\ Penulis untuk Korespondensi/E-mail: zaqiah@uai.ac.id
}

\begin{abstract}
Abstrak - Paper ini bertujuan untuk mengungkapkan masalah pembelajaran linguistik bahasa Arab di Program Studi Sastra Arab UAI dalam kegiatan perkuliahan di setiap semester dan tesis akhir. Hasil penelitian menunjukkan bahwa lebih dari $75 \%$ siswa di program studi sastra Arab menulis tesis sarjana mereka, seperti topic linguistik daripada topic lainnya. Namun, ketertarikan pada linguistic tidak diikuti oleh pemahaman dan penguasaan bahasa linguistic yang lebih baik. Dengan mewawancarai dan mengamati 20 responden siswa yang telah menyelesaikan tesis sarjana mereka, dan 4 orang dosen linguistik, masalah pembelajaran linguistik bahasa Arab akan terungkap dan solusi potensial akan diajukan.
\end{abstract}

Kata Kunci - Mata Kulia Linguistik Arab, Permasalahan, dan Solusi

Abstract - This paper aims to reveal the problems of Arabic linguistics learning in the Department of Arabic Letter UAI in the lecture activities in each semester and the final thesis. The result of the study revealed that more than $75 \%$ of students in the Department of Arabic Letter that are writing their bachelor thesis, like a linguistics topics than other topics. However, the interest in the linguistics are not followed by the better understanding and mastery about linguistics. By interviewing and observing 20 student respondents that have been finishing their bachelor thesis, and 4 linguistics lecturer respondents, the problem of Arabic linguistics learning will be revealed and the potential solutions will be proposed.

Keywords: Arabic Linguistics learning, problems, and solutions

\section{PENDAHULUAN}

\section{Latar Pokok Bahasan}

¿ inguistik adalah salah satu bidang ilmu studi bahasa dan sastra di PTN ataupun PTS di Indonesia. Tidak terkecuali program studi Sastra Arab Fakultas Sastra Universitas Al Azhar Indonesia (UAI). Sejak awal berdirinya tahun 2000, Prodi Sastra Arab UAI sudah memasukkan mata kuliah linguistik dalam kurikulumnya. Hingga saat ini, setelah kurikulum mengalami perubahan beberapa kali, bidang ilmu tersebut tetap dipertahankan. Itu dilakukan, karena linguistik memberikan perangkat analisis kebahasaan yang ilmiah dan general, serta memberikan pengetahuan teoritis dan praktis tentang ilmu kebahasaan yang dapat dipahami secara general oleh para peminat pengetahuan, baik yang menggeluti bidang bahasa ataupun sebaliknya. Dengan landasan berpikir yang demikian, para mahasiswa yang memilih prodi bahasa dan sastra Arab UAI diharapkan memiliki fondasi keilmuan yang memadai dalam mempelajari bahasa Arab dan ilmu bahasa Arab.

Secara berurutan, tataran subbidang linguistik yang diajarkan adalah pengantar linguistik Arab, fonologi, morfologi, sintaksis, semantik, pragmatik, analisis wacana, leksikologi, dan linguistik terapan. Masing-masing tataran diberikan pada setiap semester secara berurutan, dan masing-masing materi pada setiap tataran menjadi prasyarat untuk mata kuliah pada semester berikutnya. Dibuat demikian, karena penguasaan mahasiswa 
terhadap satu subbidang linguistik akan mempengaruhi proses pembelajaran pada subbidang linguistik berikutnya. Kemampuan mahasiswa yang kurang memadai pada bidang fonologi akan berdampak pada proses pembelajaran bidang morfologi yang hasilnya kurang lebih sama dengan sebelumnya. Demikian seterusnya, sehingga kesinambungan penguasaan materi pada setiap tataran menjadi syarat utama untuk memahami linguistik Arab secara menyeluruh.

Secara umum, mata kuliah linguistik Arab merupakan mata kuliah yang cukup digemari para mahasiswa prodi Sastra Arab FS UAI. Indikasi yang ditunjukkan adalah tingginya minat sebagian besar mahasiswa yang memilih bidang linguistik sebagai topik tugas akhir mereka. Lebih dari $75 \%$ mahasiswa yang sedang mengerjakan skripsi, lebih menyukai topik linguistik dibanding bidang lain. Pada mata kuliah Seminar Pra-Skripsi, bakal proposal yang mereka presentasikan lebih dominan mengetengahkan tema linguitik teoritis. Hanya satu atau dua mahasiswa yang memilih tema susastra dan budaya. Akan tetapi, kenyataan tersebut berbanding terbalik dengan pemahaman mereka terhadap linguistik Arab itu sendiri. Mereka hanya sebatas memiliki ketertarikan terhadap fenomena kebahasaan yang menggelitik untuk dikaji lebih dalam. Namun, pada tahap selanjutnya mereka tidak memiliki pemahaman yang baik terhadap fenomena tersebut. Bahkan pada tahap yang lebih ekstrim, beberapa mahasiswa tidak mengetahui apa sebenarnya yang akan dan sedang mereka kaji.

Asumsi di atas didasarkan pada pengalaman pribadi sebagai pengampu beberapa mata kuliah linguistik, dan sekaligus menjadi pembimbing tugas akhir bidang linguistik. Dalam banyak kasus, mahasiswa menjadi sangat tidak mandiri dalam memahami bidang yang mereka geluti. Kemampuan bahasa Inggris mereka yang belum memadai, ditambah keengganan mereka untuk membaca berbagai referensi, serta kecakapan analitik yang seadanya menjadi PR tersendiri bagi para dosen linguistik. Dosen harus meluangkan waktu ekstra, di luar jam kuliah, untuk membahas sebuah artikel dalam sebuah jurnal, ataupun untuk mengulang-ulang penjelasan pada sebuah bab pada buku ajar.
Kondisi yang demikian pun, bukanlah sebuah jaminan bahwa mereka akan mengerti secara benar tentang sebuah materi linguistik. Pada kenyataannya, dosen dihadapkan pada sebuah situasi yang sangat sulit untuk memahamkan mereka. Dengan kata lain, hal tersebut menjadi indikasi, bahwa ada problematika yang membutuhkan solusi.

Merujuk pada kenyataan di atas, kajian ini akan mencermati hal-hal yang menjadi kendala, bagi dosen dan mahasiswa dalam proses transfer materi linguistik Arab, baik secara formal di kelas, maupun di luar kelas. Dengan demikian, kendala tersebut dapat diidentifikasi, yang pada akhirnya, melalui riset ini pula diupayakan solusinya.

\section{Tujuan Penelitian}

Kajian ini hendak mengungkap problematika yang dihadapi oleh pengajar dan mahasiswa pada mata kuliah linguistik di lingkungan prodi Sastra Arab UAI dalam kegiatan perkuliahan pada setiap semester. Problematika yang dimaksud dapat ditinjau dari berbagai faktor, antara lain faktor pengajar dan mahasiswa, faktor bahasa, faktor metode pengajaran, dan faktor sarana. Dengan mengindentifikasi problematika yang ada, riset ini mencoba mencarikan solusi yang tepat, agar problematika tersebut dapat diminimalisir atau bahkan tidak ditemukan lagi pada masa yang akan datang.

\section{Rumusan Masalah}

Berdasarkan uraian pada sub-bab sebelumnya, penelitian ini hendak mendeskripsikan dan memetakan problematika yang sering dihadapi dalam perkuliahan linguistik. Problematika yang menjadi tantangan sekaligus kendala dalam perkuliahan linguistik ini akan, dikaji solusinya sehingga materi linguistik Arab menjadi mudah dipahami oleh mahasiswa.

\section{Ruang Lingkup}

Kajian ini akan berfokus pada pengajaran linguistik Arab untuk mahasiswa prodi Sastra Arab angkatan 2011 dan 2012. Mahasiswa pada dua angkatan tersebut sudah memperoleh materi linguistik yang dimulai dari semester satu hingga semester enam. Pada semester tujuh mereka sudah mengikuti mata kuliah Seminar Pra-Skripsi. Pada mata kuliah tersebut, mahasiswa yang memilih topik linguistik untuk 
tugas akhir mereka, diberi kesempatan untuk mengeskplorasi kompetensi linguistik mereka.

\section{Kontribusi Penelitian}

Hasil riset ini akan memberikan gambaran tentang problematika pengajaran linguistik Arab di prodi Sastra Arab FS UAI. Solusi untuk problematika yang sudah teridentifikasi tersebut, akan sangat membantu proses belajar mengajar serta proses bimbingan tugas akhir mahasiswa. Ketimpangan antara minat mahasiswa yang besar terhadap bidang linguistik dan pemahaman mereka yang masih minim akan diminimalisir bahkan dihilangkan.

\section{TINJAUAN PUSTAKA}

\section{Pengantar}

Bukanlah hal yang mudah untuk menemukan kajian yang khusus menyoroti pembelajaran linguistik pada sebuah institusi. Sebagian besar artikel, bahkan semua artikel yang diperoleh merupakan hasil penelitian tentang problematika pengajaran bahasa asing atau bahasa kedua beserta solusinya. Pembelajaran linguistik yang menjadi kata kunci mengarahkan pada artikel tentang pembelajaran bahasa sebagai objek linguistik, atau pembelajaran bahasa sebagai bahasa kedua, dan lain-lain.

Pembelajaran linguistik itu sendiri pada hakikatnya dimulai dari mempelajari sebuah bahasa, baik itu bahasa pertama ataupun bahasa kedua, dan seterusnya. Ketika seorang anak lahir dan berkomunikasi dengan orang-orang di sekelilingnya, pada kegiatan yang demikian, dapat dikatakan sebuah pembelajaran linguistik, yakni melihat pemerolehan bahasa seorang anak, sejak ia lahir. Ketika seseorang belajar bahasa asing sebagai bahasa kedua, baik secara formal maupun informal, fenomena tersebut juga menjadi ranah pembelajaran linguistik. Artinya, proses memperoleh sebuah bahasa, baik dengan cara belajar di kelas secara formal, ataupun sebaliknya dapat disebut sebagai proses pembelajaran linguistik. Akan tetapi, ada perbedaan mendasar yang perlu digarisbawahi antara belajar bahasa dan belajar linguistik sebuah bahasa. Secara umum, belajar bahasa berarti mempelajari empat kemahiran berbahasa yaitu, membaca, menulis, mendengar, dan berbicara dalam bahasa tertentu. Sementara belajar linguistik, berarti tidak hanya mempelajari empat kemahiran berbahasa, tetapi juga mempelajari fenomena kebahasaan yang unik dan universal. Selain itu, tidak hanya menyangkut sebuah bahasa tertentu. Fenomena kebahasaan yang dimaksud, erat kaitannya dengan semua aktifitas yang menggunakan bahasa, baik bahasa lisan maupun tulisan.

\section{Pembelajaran Bahasa Kedua \\ Beberapa Teori Tentang Pemerolehan Bahasa Kedua}

Ada banyak teori yang mencuat tentang pemerolehan atau pembelajaran bahasa kedua sejak beberapa abad silam. Yang paling dikenal adalah yang dicetuskan oleh kelompok Behaviorism. Sebenarnya kelompok ini tidak hanya menyoroti bidang linguistik, tetapi selalu melakukan investigasi ilmiah pada semua bidang. Aliran ini menyatakan bahwa perilaku manusia dapat dipelajari melalui proses stimulus (S), response (R), dan dorongan positif/negatif (reinforcement-R) yang ada dalam diri manusia. Ini juga berlaku pada manusia dalam memperoleh atau mempelajari bahasa; sama halnya dengan perilaku manusia yang lainnya.

Pendapat yang berbeda disampaikan oleh Chomsky. Menurutnya, data kebahasaan yang diobservasi dalam pemerolehan bahasa tidak selaras dengan konsep yang disampaikan behaviorist. Setiap anak memperoleh bahasanya pada usia yang sangat dini. Mereka dapat berbahasa dengan menggunakan bahasa yang mereka ciptakan sendiri, bukan dengan mengimitasi bahasa atau apa yang mereka dengar di sekeliling mereka. Mereka memiliki apa yang ia sebut dengan innate ability untuk memperoleh bahasa. Setiap tahapan perkembangan kemampuan kognitif pada masing-masing anak tidak dapat diasosiasikan dengan proses mempelajari bahasa. Artinya, bahasa itu bukan dipelajari oleh anak-anak, tetapi digunakan oleh mereka karena adanya kapasitas yang memungkinkan mereka dapat berbahasa. Pada hakikatnya, Chomsky tidak terlalu peduli dengan bahasa yang diujarkan ataupun tidak diujarkan. Ia hanya berfokus pada aturan yang membuat ujaran itu dapat dipahami oleh masing-masing penutur. Hal yang sangat penting yang harus dinyatakan di sini adalah bahwa chomsky sendiri tidak pernah mengkaji bagaimana manusia 
memperoleh bahasa keduanya. Akan tetapi, para pengikutnyalah yang banyak menerapkan konsep yang sama untuk pemerolehan bahasa kedua.

Pakar ilmu yang menyanggah pendapat Chomsky tersebut adalah R.C. Anderson. Ia mengembangkan apa yang disebut dengan model ACT (Adaptive Control of Thought), yaitu sebuah model yang banyak berpengaruh pada studi tentang perkembangan kognitif dan pemerolehan bahasa kedua. Dalam teorinya, Anderson menjelaskan bahwa intelegensia merupakan kumpulan unit-unit kecil pengetahuan yang dibuat fine-tuning, yang secara menyeluruh memproduksi complext thinking. Semua kemampuan dan kapasitas belajar bahasa yang ada dalam diri manusia tidak lebih dari akumulasi bagian-bagian dari complext thinking tadi; dan ia memiliki bagitu banyak bagian-bagian. Secara umum, teori ini berbasis pada hipotesis yang menyatakan pengetahuan yang dimiliki manusia dibagi menjadi 2, yaitu declarative knowledge dan procedural knowledge. Declarative knowledge dipelajari secara terus menerus, dan disimpan dalam memori untuk jangka panjang. Sementara procedural knowledge adalah tahapan proses yang lebih kompleks yang menjadi wadah bagi manusia untuk belajar melakukan sesuatu dengan baik. Poin utama dalam teori ini adalah bahwa pemerolehan bahasa kedua dimulai dengan declarative knowledge, yang kemudian secara bertahap menjadi procedural knowledge hingga manusia memperoleh bahasanya.

Tiga teori tentang pemerolehan bahasa kedua di atas memang hanya menyajikan bagaimana bahasa kedua diperoleh oleh seseorang secara konseptual dan praktikal. Itu tidak berhubungan langsung dengan proses pembelajaran linguistik. Akan tetapi, tidak ada teori yang khusus mengetengahkan pembelajaran linguistik ketika seseorang memperoleh atau mempelajari sebuah bahasa. Disebut pembelajaran linguistik, karena ketika seseorang memperoleh bahasa kedua, innately ia memperoleh pengetahuan linguistik, walaupun tidak eksplisit.

\section{Beberapa Kajian tentang Pemerolehan Bahasa Kedua}

Ada pula yang menyoroti tinjauan teoritis dari pemerolehan bahasa untuk orang asing. Ini dikaji oleh Basuki (1999) yang menulis dalam sebuah e-jurnal BIPA STKIP Singaraja. Ia menyebutkan dua pendekatan yang menyangkut second language acquasition (SLA), yaitu formalis dan fungsionalis. Menurut pendekatan formalis bahasa adalah bentuk dan pengajarannya berpusat pada pengajaran bentuk-bentuk bahasa. Sementara itu, pendekatan fungsionalis yang berakar pada bidang sosiolinguistik menekankan aspek fungsi. Tampaknya, Basuki merujuk pada artikel Hurford (1990) yang lebih awal mengkaji dua pendekatan tersebut.

Sementara Shafa (2102) mencoba mencermati teori pemerolehan bahasa dan implikasinya dalam pembelajaran. Ia menjelaskan bahwa pemerolehan bahasa kedua dibagi menjadi dua tipe, yaitu natural dan formal. Tipe natural menggambarkan bahwa bahasa diperoleh oleh anak-anak atau pun orang dewasa melalui interaksi mereka dengan masyarakat sekeliling mereka. Masyarakat tempat mereka bergaul dalam keseharian akan "memaksa" dan melatih mereka memahami bahasa yang digunakan dalam aktifitas sehari-hari. Dengan cara ini, seiring berjalannya waktu, mereka akan menguasai bahasa itu secara alamiah tanpa belajar formal di kelas. Dari kenyataan ini, sebenarnya ia hendak menyatakan bahwa belajar bahasa secara formal di kelas belum tentu lebih baik dengan mereka yang memperoleh bahasa melalui interaksi. Untuk mendukung pendapatnya tersebut, ia menyampaikan paham behavioristics bahwa baik bahasa pertama maupun bahasa kedua, dapat dikuasai dengan cara berlatih. Latihan yang dimaksud adalah rangsangan dan respon rangsangan yang terjadi timbal balik antara pemeroleh bahasa dan orang-orang di sekelilingnya. Ia menambahkan teori dari mentalistic bahwa setiap insan dilahirkan membawa innate competency to own the language. Dengan demikian, menurut paham ini, language is not a habit, sehingga orangorang tidak membutuhkan belajar bahasa, tetapi cukuplah berinteraksi dengan orang lain yang sudah menguasai bahasa itu.

\section{Pembelajaran Bahasa Arab Sebagai Bahasa Kedua}

Beberapa artikel yang membicarakan problematika pengajaran bahasa Arab sebagai bahasa kedua sudah banyak ditemukan dalam jurnal ilmiah. Di antara yang pernah membahas 
hal tersebut adalah Hidayat (2012) dan Fahrurozi (2014). Pada paparan mereka dalam artikel tersebut, keduanya menjelaskan problem utama dalam pembelajaran bahasa Arab ada dua, yaitu problem linguistik dan problem non linguistik. Aspek yang banyak dikeluhkan dari problem linguistik dapat dijabarkan dalam empat tataran, yakni fonologis, kosakata, tata bahasa dan struktur kalimat. Adapun yang menyangkut problem non linguistik adalah masalah kesiapan siswa dan pengajar, motivasi siswa dan pengajar, serta tujuan pembelajaran bahasa Arab.

Hidayat menyatakan bahwa istilah pembelajaran erat kaitannya dengan dua istilah lain, yaitu belajar dan mengajar. "Belajar" dilihat dari sisi siswa, sedangkan "mengajar" dilihat dari sisi pengajar atau guru. Sebelum memaparkan hasil penelitiannya, ia menjelaskan terlebih dahulu definisi belajar dan definisi mengajar. "Belajar" adalah suatu proses usaha yang dilakukan seseorang untuk memperoleh suatu perubahan tingkah laku yang baru secara keseluruhan sebagai hasil pengalamannya sendiri dalam interaksi dengan lingkungannya. Adapun "mengajar" adalah suatu usaha untuk menciptakan kondisi atau sistem lingkungan yang mendukung dan memungkinkan untuk berlangsungnya proses belajar.

Dari sini, dapat dikatakan bahwa keberhasilan pembelajaran bahasa Arab harus dicermati dari dua sisi, yakni siswa dan gurunya. Pembelajaran bahasa Arab akan memperoleh hasil yang maksimal, jika dua sisi tersebut sama baiknya, dan disertai aspek non linguistik lainnya, yaitu yang terkait dengan media pembelajaran, metode mengajar guru dan metode belajar siswa, serta evaluasi dan penilaian. Akan tetapi, dalam analisisnya, ia menyebutkan bahwa bahasa Arab itu sendiri memiliki karakteristik yang kompleks dan unik. Kompleksitas dan keunikan bahasa Arab itu acapkali menjadi kendala bagi para pembelajarnya. Dengan kata lain, Hidayat ingin menyatakan bahwa problematika belajar bahasa Arab itu, bukan hanya berasal dari siswa dan pengajarnya, tetapi dari bahasa Arab itu sendiri. Di akhir tulisannya, ia memiliki kesimpulan yang sama dengan fakhrurozi, bahwa pembelajaran bahasa Arab itu menjadi terkendala oleh dua hal, yaitu problematika linguistik dan non linguistik.

\section{Pembelajaran Linguistik}

Linguistik adalah ilmu tentang bahasa (Kridalaksana dalam Kushartanti dkk., 2007: 7). Linguistik digolongkan sebagai salah satu cabang ilmu pengetahuan budaya atau humaniora. Penggolongan ini dicetuskan oleh Jean Piaget (dalam Kushartanti dkk, 2007: 12). Mereka yang mempelajari linguistik akan memperoleh manfaat langsung ketika memperdalam ilmu-ilmu yang berkaitan dengan bahasa.

Setakat ini, kajian yang berusaha mengidentifikasi masalah pembelajaran linguistik secara umum, ataupun yang khusus menyangkut bahasa tertentu belum ditemukan. Ini dapat terjadi, karena mengajarkan atau mempelajari bahasa tertentu tidak serta merta mengajarkan dan mempelajari masalah linguistiknya. Walaupun, dapat diasumsikan bahwa sebuah bahasa ketika diajarkan ataupun dipelajari, secara tidak langsung menyajikan aspek linguistik. Namun, boleh jadi pembelajar bahasa tersebut, dan pengajarnya tidak menyadari adanya aspek linguistik yang "terikutkan" ketika belajar dan mengajar bahasa itu. Mengapa demikian? Ketika seseorang belajar ataupun mengajar sebuah bahasa, ia akan mempelajari ataupun mengajarkan pelafalan dan struktur gramatikal bahasa itu. Struktur gramatikal itu sendiri merupakan kajian morfologi dan sintaksis, yang menjadi salah satu bagian dari ranah linguistik. Begitu juga dengan pelafalan, yang masuk dalam kajian fonologi. Namun, yang menjadi fokus adalah bahasanya bukan linguistiknya. Itu berarti, para pembelajar bahasa itu, hanya berusaha memahami kaidahkaidah yang ada dalam bahasa itu, agar mereka dapat menggunakannya untuk komunikasi; tidak untuk yang lain.

Demikian pula dengan para pembelajar bahasa Arab. Mereka yang sudah belajar bahasa Arab, dan sudah memiliki kemampuan pada level mahir dalam berbahasa Arab lisan dan tulisan, belum dapat dipastikan memiliki pemahaman yang baik tentang linguistik Arab. Bahkan, nilai A pada tugas akhir mereka, bukan pula menjadi indikasi bahwa mereka menguasai topik mereka dengan baik. Sebagian besar dari mereka, jika ditanya dengan pertanyaan sederhana tentang linguistik, tidak dapat memberikan jawaban yang logis dan ilmiah. 
mereka tidak memiliki pemahaman yang baik tentang linguistik.

Jika mengacu pada beberapa artikel yang bertema problematika pembelajaran bahasa, kajian ini juga tampaknya memiliki alur dan format berpikir yang sama. Yang menjadi faktor kendala dalam memahami linguistik Arab itu, sementara ini, berdasarkan asumsi adalah faktor internal mahasiswa, dan faktor eksternal mahasiswa. Faktor internal meliputi kompetensi dan motivasi mahasiswa, sedangkan faktor eksternal meliputi materi linguistik yang sulit dipahami, metode mengajar dosen, dan referensi yang banyak berbahasa asing.

\section{METODOLOGI PENELITIAN}

\section{Pengantar}

Bab ini memuat sejumlah informasi tentang metode yang digunakan dalam kajian ini, data dan sumber data, serta teknik analisis yang akan digunakan dalam membahas dan memperlakukan data.

Sebagai penelitian kualitatif, data yang diperoleh dari kuesioner akan dicermati jawabannya bukan dengan pembobotan tetapi sebagai sebuah uraian bermakna tentang sebuah topik.

\section{Metode Penelitian}

Dengan menggunakan pendekatan kualitatif, riset ini bersifat eksploratif. Metode penelitian dan analisis data berbentuk deskriptif, menyajikan temuan yang dianalisis berdasarkan teori yang ada, serta menyimpulkan temuan tersebut sebagai hasil akhir dari kajian ini.

\section{Data dan Sumber Data}

Data penelitian ini adalah informasi dari mahasiswa dan dosen prodi Sastra Arab tentang problematika pembelajaran linguistik Arab yang mereka hadapi. Data diperoleh melalui pengisian kuesioner, wawancara, observasi, dan dokumentasi. Wawancara dilakukan kepada lulusan angkatan 2012 dan angkatan 2011. Artinya, yang menjadi responden adalah mereka yang sudah menyelesaikan tugas akhir, dan bidang minat yang diambil adalah linguistik. Secara keseluruhan mereka berjumlah 20 orang, yang terdiri atas 7 mahasiswa dan 13 mahasiswi. Masing-masing akan diminta mengisi kuesioner yang telah disediakan, kemudian dilanjutkan dengan wawancara terstruktur. Wawancara yang demikian dilakukan untuk memperoleh jawaban yang objektif, namun tetap terarah sesuai dengan topik kajian.Adapun untuk para dosen pengajar linguistik, hanya wawancara yang dilakukan. Ada 4 dosen pengajar linguistik di prodi Sastra Arab UAI, yang menjadi responden dalam penelitian ini. Hasil wawancara dengan para dosen akan dikomparasikan dengan jawaban dari responden mahasiswa, ketika menganalisis data.

Observasi dilakukan ketika perkuliahan mata kuliah linguistik sedang berlansung. Selain itu, kegiatan bimbingan tugas akhir juga menjadi salah satu unit yang diamati. Ketika bimbingan berlangsung, arahan dari dosen pembimbing dan kesiapan mahasiswa dalam menyiapkan materi setiap bab dapat dijadikan bahan pengamatan. Dari situasi tersebut, dapat diperoleh informasi tentang hal-hal yang menjadi kendala, baik bagi mahasiswa maupun dosen pembimbing., terkait proses penyelesaian tugas akhir

\section{Teknik Analisis Data.}

Data dalam penelitian ini adalah informasi yang dihimpun dari jawaban responden terhadap pertanyaan-pertanyaan dalam kuesioner, dan jawaban mereka dalam wawancara. Jawaban tersebut dilihat dari dua sisi, yaitu sisi mahasiswa dan dari sisi pengajar. Kolaborasi dua sisi jawaban tersebut diklasifikasi berdasarkan faktor internal dan faktor eksternal. Yang dimaksud dengan faktor internal adalah faktor-faktor yang berasal dari dalam diri mahasiswa yang menjadi penghambat ataupun kendala dalam pembelajaran linguistik Arab, di antaranya kompetensi akademik, motivasi, dan ketekunan. Adapun faktor eksternal adalah faktor penghambat yang berasal dari luar diri mahasiswa, misalnya kurikulum, metode pengajaran, materi linguistik itu sendiri.

Setiap informasi dari responden dipaparkan dan dianalisis secara kualitatif dengan membuat kontras ataupun cek silang dengan hasil observasi dan hasil wawancara dosen. Dengan demikian, problematika pembelajaran linguistik Arab dapat diidentifikasi secara objektif, karena tidak dilihat dari sisi mahasiswa semata, 
tetapi didukung oleh jawaban dari dosen dan pengamatan langsung. Setelah itu, berdasarkan problematika yang telah dipaparkan, diupayakan solusi yang tepat dan efektif.

\section{PEMBAHASAN}

\section{Profil Responden}

Responden penelitian ini adalah lulusan Prodi Sastra Arab yang telah menyelesaikan tugas akhir di tahun 2015-2016. Mereka adalah mahasiswa angkatan 2011 dan angkatan 2012. Ada 20 responden yang berhasil dihubungi melalui email dan telepon. Mereka terdiri dari 13 mahasiswi dan 7 mahasiswa. Melihat kompetensi akademik, responden tersebut dibagi menjadi dua, pertama yang memiliki IPK dibawah 3.50; dan kedua yang memiliki IPK di atas 3.50. Klasifikasi ini didasarkan pada pengamatan dan pengalaman mengajar, serta pengalaman menjadi sekretaris program studi. Di antara 70 mahasiswa aktif di prodi sastra Arab, lebih dari 60\% mahasiswa memiliki IPK lebih dari 3.00. Namun, dalam konteks pembelajaran linguistik, IPK yang demikian tidak dapat dijadikan indikasi bahwa mahasiswa memiliki pemahaman yang baik tentang materi linguistik. Bahkan, mereka yang memperoleh predikat cumlaude pun, dengan topik tugas akhir di bidang linguistik, belum dapat dipastikan memahami secara excellent topik mereka. Namun, ada satu atau dua orang mahasiswa yang memang dapat dikatgorikan cakap, paham, dan menguasai materi linguistik. Berikut adalah tabel profil responden berdasarkan nilai MK linguistik, toefl, dan IPK.

\section{Problematika Pembelajaran Linguistik Arab}

Sebagaimana yang telah dinyatakan sebelumnya bahwa pembelajaran linguistik Arab yang dimaksud dalam kajian ini berkaitan dengan proses belajar linguistik yang dialami mahasiswa sastra Arab UAI. Namun, dalam mengkaji proses belajar tersebut, ada dua pihak yang akan dilibatkan, yaitu mahasiswa dan dosen. Itu dilakukan karena sebuah proses pembelajaran dikatakan berhasil ataupun sebaliknya, pastilah melibatkan dua pihak tadi, di samping hal lain di luar keduanya.

\section{Mahasiswa}

Problematika pembelajaran linguistik Arab ini didasarkan pada kuesioner dan wawancara terhadap responden mahasiswa. Pada umumnya, setiap responden menyatakan belum pernah mengenal istilah "linguistik" sebelum belajar di program Studi Sastra Arab UAI. Artinya, linguistik adalah ilmu baru bagi mereka. Mereka biasanya baru menyadari kalau ternyata selama ini mereka telah bersentuhan dengan linguistik. Namun, para pengajar bahasa mereka di sekolah sebelumnya, tidak pernah memperkenalkan istilah tersebut. Sekalipun istilah itu adalah sesuatu yang baru buat responden, ternyata sebagian besar dari mereka, dapat memberikan penjelasan tentang definisi linguistik. Ada tiga responden yang memaparkan konsep linguistik secara tidak tepat. Menurut mereka, linguistik adalah ilmu yang berkaitan dengan masalah internal bahasa. Hanya itu. Sebaliknya, ketika responden diminta untuk menjelaskan tentang wilayah kajian linguistik, hampir semua responden (18 orang) menjelaskan bahwa linguistik mempelajari fonologi, morfologi, sintaksis, semantik, pragmatik, dan leksikologi. Padahal cakupan kajian linguistik sangat luas, meliputi mikro dan makro linguistik. Tampaknya, jawaban ini diperoleh dari nama mata kuliah linguistik yang diajarkan di prodi Sastra Arab UAI. Mereka seolah melupakan bidang makro linguistik yang banyak berinteraksi dengan disiplin ilmu lain dan bidang terapan. Pada mata kuliah Pengantar Linguistik Arab, kajian linguistik yang sangat beragam dan mengikuti konsep kekinian sudah diperkenalkan sebagai materi dasar. Dalam bab awal MK Pengantar Linguistik Arab, mahasiswa diperkenalkan dengan filosofis linguistik sebagai sebuah bidang ilmu. Mereka dipahamkan tentang konsep bahasa secara menyeluruh sebagai sebuah sistem yang arbitrer, serta keunikan dan keuniversalan yang dimiliki bahasa Arab. Mereka juga memperoleh penjelasan tentang kajian-kajian dalam linguistik, dan beberapa contoh kajian tersebut dalam linguistik Arab. Selain itu, pengenalan tentang linguistik murni, linguistik teoritis, dan linguistik terapan juga disajikan pada mata kuliah linguitik pertama di semester satu ini.

Akan tetapi, ketika para responden diminta menyatakan pandangan mereka tentang payung besar linguistik, linguistik menjadi sangat sempit. Kenyataan tersebut memperlihatkan bahwa mahasiswa tidak memiliki pemahaman dasar yang baik tentang kajian linguistik, yang seharusnya mereka peroleh pada semester satu dalam mata kuliah Pengantar Linguistik Arab. 
Mereka memahami linguistik masih terbatas pada apa yang mereka ingat dari nomenklatur mata kuliah yang diajarkan di kelas.

Fenomena di atas erat kaitannya dengan pustaka atau referensi linguistik yang pernah mereka baca selama berkuliah di prodi Sastra Arab FS UAI. Hampir semua responden (16 orang) menyebutkan pustaka yang kurang lebih sama, yaitu buku-buku yang menjadi pegangan untuk kuliah. Sumber lain selain buku pegangan, yang mereka sebutkan adalah power point dan diktat dari dosen pengampu mata kuliah tersebut. Hanya 4 responden yang menyatakan pernah membaca beberapa pustaka linguistik yang fundamental. Biasanya, mereka membaca pustaka yang demikian menggunakan google translate, atau bahkan terkadang meminta dosen untuk memahamkan mereka tentang isi buku secara garis besar. Pustaka yang dimaksud ada yang berbahasa Arab, dan ada pula yang berbahasa Inggris. Dari pengamatan kami, sebagian besar mahasiswa merasa "alergi" dengan tulisan yang berbahasa asing. Mereka akan memperlihatkan mimik muka penolakan ketika dosen meminta untuk membaca buku-buku yang berbahasa Arab ataupun berbahasa Inggris. Penolakan itu semakin terlihat hasilnya, ketika mereka tidak dapat menjelaskan konsep atau isi buku tersebut. Artinya, mereka memang berusaha memenuhi permintaan dosen untuk membaca referensi tertentu yang berbahasa Inggris, namun, hasil bacaan yang mereka paparkan di kelas belum mencerminkan isi bacaan yang sebenarnya. Itu berarti tugas dosen menanti untuk menjelaskan isi buku secara garis besar. Ini tidak terjadi pada satu atau dua mahasiswa di kelas. Dalam kasus seperti ini, dosen dihadapkan pada dilema yang panjang. Kemandirian mahasiswa untuk menyelesaikan masalahnya sendiri menjadi dipertanyakan. Mahasiswa tidak berusaha maksimal untuk menguasai isi buku agar dapat dipaparkan di hadapan teman-teman di kelas. Mereka menjadi mahasiswa yang minimalis, sekadar menunaikan tugas. Paradigma berpikir mahasiswa yang sangat ala kadarnya ini secara objektif mendominasi kelas. Untuk mencapai target pemahaman, dosen akan mengambil alih, menjelaskan materi dalam pustaka yang dimaksud. Jika itu tidak dilakukan dosen, pemahaman yang keliru terhadap konten dari sebuah pustaka linguistik akan diterima anggota kelas. Kenyataan yang demikian juga terjadi saat bimbingan tugas akhir. Jika mereka tidak dibantu oleh dosen, mereka akan menghilang dalam waktu yang lama sehingga menjadi mahasiswa kritis dilihat dari masa studi.

Demikian pula dengan artikel pada jurnal ilmiah. Ada keengganan tersendiri dari dalam diri mahasiswa untuk mencari artikel yang terkait dengan topik penelitian mereka. Kondisi ini semakin buruk, apabila artikel yang harus dimasukkan dalam penelitian mereka adalah yang berbahasa Arab ataupun berbahasa Inggris. Ini dapat dibuktikan dengan membuka halaman daftar pustaka pada skripsi mereka. Tidak sampai $20 \%$ dari responden yang mengambil artikel jurnal untuk dimasukkan dalam bab Tinjauan Pustaka dan Kajian Terdahulu.

Situasi yang sangat memperihatinkan dan sangat menggelitik terkait paparan bab Tinjauan Pustaka dan Kajian Terdahulu adalah pada saat bimbingan skripsi dan atau sidang skripsi. Mahasiswa menyajikan ulasan mereka tentang kajian yang pernah ada terkait topik yang mereka ambil. Namun, ketika mereka diminta menjelaskan secara sistematis isi pustaka yang dimaksud, sebagian besar dari mereka membaca ulang isi pustaka, bukan menjelaskan secara kronologis dan sistematis signifikansi dan relevansi dari pustaka yang dijadikan acuan. Dalam konteks ini, dapat dikatakan bahwa mereka hanya memindahkan isi pustaka ke dalam skripsi mereka, tanpa mengetahui substansi dari isi buku, dan relevansinya dengan riset yang mereka lakukan.

Beberapa pertanyaan dalam kuesioner yang mengeksplorasi pendapat responden tentang referensi linguistik, menunjukkan bahwa materi linguistik itu memang sulit. Hanya satu orang yang menyatakan bahwa linguistik itu bukanlah hal yang sulit. Memahami linguistik menurutnya memerlukan kesungguhan untuk membaca banyak referensi. Jika itu tidak dilakukan, kesulitan mencerna penjelasan dosen di kelas pastilah tidak dapat dielakkan. Tampaknya, pendapat ini sangat realistis. Artinya, kesulitan yang dihadapi oleh para responden, pada hakikatnya, diciptakan oleh mereka sendiri yang memang tidak memiliki usaha maksimal untuk memperoleh materi linguistik. Namun, itu bukanlah satu-satunya 
alasan bagi responden untuk menyatakan bahwa linguistik itu adalah kajian yang tidak mudah. Faktor lain adalah kompetensi akademik mahasiswa yang memang terbatas. Disebut demikian, karena kompetensi akademik itu ditunjukkan oleh rendahnya kemampuan analitik mereka ketika diberikan tugas di kelas. Ketika dosen menjelaskan sebuah konsep, misalnya tentang alofon, dosen akan menguraikan definisi alofon, dan memberikan contohnya dalam bahasa Arab, bahwa alofon adalah variasi bunyi dari sebuah fonem, atau keanggotaan bunyi dari sebuah fonem, atau realisasi bunyi dari sebuah fonem. Saat dosen meminta mahasiswa untuk mengulang penjelasan tentang alofon dan memberikan contoh lainnya dalam bahasa Arab, jarang sekali ada di antara mahasiswa yang dapat memahami definisi tersebut. Dosen harus mengulang penjelasan hingga beberapa kali, barulah ada satu dua orang yang mulai paham. Dari kasus ini, ada sebuah gambaran bahwa kemampuan mencerap materi itu memang rendah.

Kondisi di atas semakin diperburuk oleh salah satu kasus berikut. Para dosen linguistik, biasanya sebelum memulai materi kuliah akan menanyakan materi yang sudah dibahas pada pekan sebelumnya. Namun, Jarang sekali di antara mahasiswa, ada yang dapat menjelaskan materi pekan sebelumnya. Mereka sudah lupa dengan bahasan yang telah disampaikan, sehingga materi berikutnya yang erat kaitannya dengan materi sebelumnya menjadi tidak mudah untuk dipahami. Bahkan, pada banyak kesempatan dosen harus mengulang kembali topik pekan sebelumnya, agar materi hari ini dapat diterima dengan baik.

Terkait pustaka linguistik, memang perlu keseriusan dan kosentrasi penuh untuk memahaminya. Namun, permasalahannya bukan terletak pada bidang "linguistik" nya yang sulit. Semua bidang ilmu membutuhkan konsentrasi dan keseriusan untuk memahami pustakanya. Artinya, setiap mahasiswa yang memutuskan untuk mengambil bidang tertentu sebagai tempat ia belajar, harus memiliki komitmen yang baik untuk fokus dan berkosentrasi penuh pada bidang yang ia tekuni. Komitmen itu yang masih perlu dipertanyakan dalam diri kebanyakan mahasiswa. Di antara para mahasiswa, hanya segelintir yang memiliki komitmen demikian.
Adapun pertanyaan tentang alasan mereka memilih bidang linguistik sebagai topik tugas akhir mereka, lebih dikarenakan proporsi mata kuliah bidang minat tidak seimbang di prodi Sastra Arab. Sebagian besar para responden menjelaskan bahwa mereka memperoleh mata kuliah linguistik dari semester satu hingga semester akhir. Kenyataan itu yang membuat mereka cenderung memilih linguistik untuk skripsi mereka. Mereka juga memperoleh mata kuliah bidang susastra dan budaya, namun tidak sebanyak bidang linguistik. Ada juga yang menyatakan bahwa dosen prodi Sastra Arab FS UAI lebih banyak yang berkonsentrasi pada bidang linguistik, dibandingkan bidang susasatra dan budaya.

Kenyataan itu benar adanya. Adalah hal yang sangat wajar, jika sebagian besar mahasiswa memilih bidang linguistik sebagai topik skripsi mereka. Informasi dan materi linguistik yang masuk dalam kognisi mereka jauh lebih banyak dibandingkan bidang lain. Dengan kata lain, pilihan mereka bukan didasarkan pada keinginan dan kesukaan mereka terhadap linguistik, tetapi lebih dipengaruhi situasi dan kondisi di prodi Sastra Arab, khususnya yang terkait kurikulum dan pengajar. Akan tetapi, ada beberapa responden yang menyatakan bahwa mereka memang tertarik dengan bidang linguistik, sejak diperkenalkan di semester satu. Menurut mereka, fenomena dalam kajian linguistik adalah fenomena keseharian kita dalam berbahasa, dan berinteraksi menggunakan bahasa. Gejala-gejala kebahasaan yang merupakan sebab dan akibat dari proses berbahasa adalah hal yang menarik untuk dikaji. Apalagi dalam kajian linguistik Arab di Indonesia, yang dirasa masih sangat kurang.Yang memiliki pemikiran demikian hanya 2 orang dari responden.

\section{Dosen \\ Ada tiga dosen linguistik yang secara sinambung mengajar mata kuliah linguistik di setiap semester. Mata kuliah yang dimaksud secara berurutan dari semester satu hingga semester enam adalah Pengantar Linguistik Arab, Fonologi Arab, Morfosintakasis Arab, Semantik-Pragmatik Arab, Analisis Wacana, Sosiolinguistik, Psikolinguistik, dan Leksikologi-Leksikografi Arab.}

Ketiga dosen menyatakan bahwa kompetensi akademik mahasiswa dalam mencerap materi 
linguistik di kelas sangat beragam. Namun, yang paling dominan adalah mereka yang tidak mampu mencerap materi dengan satu kali penjelasan. Masing-masing dosen memperoleh pengalaman yang hampir sama tentang hal itu. Materi yang sederhana sekalipun membutuhkan penjelasan yang tidak cukup sekali. Ini berarti berhubungan dengan innate ability yang diungkapkan oleh Chomsky sebagai alat untuk memperoleh bahasa. Namun, dalam konteks ini, kapasitas itu digunakan untuk mencerap materi linguistik, bukan untuk memperoleh bahasa, baik bahasa pertama, ataupun bahasa kedua. Dari sini, dapat dikatakan bahwa innate ability pada tiap-tiap responden itu variatif, bahkan cenderung rendah untuk kasus ini.

Selain itu, para dosen memang menyadari bahwa pustaka bidang linguistik bukanlah bacaan yang mudah untuk dipahami, tetapi bukan pula berarti tidak dapat dipahami. Usaha yang maksimal dari mahasiswa dan innate ability yang baik lah yang membuat mereka dapat dengan mudah memahami pustaka linguistik. Akan tetapi, tidak cukup hanya dengan dua hal itu saja, harus ada kecakapan berbahasa Inggris dan berbahasa Arab. Kemampuan bahasa Inggris dan kemampuan bahasa Arab yang baik, sangatlah dibutuhkan untuk membaca pustka linguistik. Ini juga menjadi salah satu problem yang banyak dialami oleh para mahasiswa. Sebagian besar responden mengalami kesulitan, ketika dosen menyerahkan sebuah artikel berbahasa Inggris atau berbahasa Arab untuk dibaca dan dipresentasikan. Apa yang mereka presentasikan, terkadang tidak sesuai dengan muatan dalam artikel itu. Itu karena faktor bahasa. Mereka mengandalkan google translate untuk memahami isi artikel. Akibatnya, paparan mereka tidak mencerminkan substansi isi artikel. Pada kasus yang demikian, dosen mengambil alih menjelaskan isi artikel. Hal itu akhirnya dilakukan dosen agar pemahaman yang keliru tentang sebuah kajian tidak menyebar dalam satu kelas. Artinya, dosen bertugas meluruskan pemahaman yang kurang tepat terhadap sebuah kajian dalam artikel jurnal. Dengan demikian, pemahaman yang keliru dari satu orang yang presentasi tidak disajikan kepada teman-teman sekelasnya.

Bagian yang juga paling sering dikeluhkan para dosen adalah masalah ketekunan mahasiswa. Dosen acap kali mendapati mahasiswa yang memiliki ketekunan yang sangat rendah. Di antara mahasiswa yang menjadi responden dalam penelitian ini, hanya 5 orang yang dapat dikategorikan rajin dan tekun. Pada umumnya, mereka yang tekun adalah mereka yang memang memiliki etos belajar yang baik, innate ability yang sama baiknya, kemampuan bahasa Inggris yang memadai, serta academic performance yang baik.

\section{Solusi terhadap Problematika}

Merujuk pada paparan tentang problematika pembelajaran linguistik Arab di atas, dapat dipetakan bahwa hal-hal yang menjadi penghambat atau kendala dalam mempelajari linguistik Arab dapat dilihat dari dua faktor, yaitu

1. Faktor internal. Ini yang disebut Chomsky sebagai innate ability yang dimiliki oleh semua manusia dalam belajar bahasa. Dalam konteks pembelajaran linguistik Arab di prodi Sastra Arab FS UAI, innate ability itu tidak hanya menyakut LAD (Language Acquasition Device), tetapi juga kapasitas perangkat kognitif yang dimiliki semua manusia untuk menerima masukan dari luar, kemudian mengolahnya dalam proses berpikir, dan mengekspresikannya. Berdasarkan uraian sebelumnya, bagian ini mencakupi (1) motivasi mahasiswa, (2) kompetensi akademik mereka yang wujudnya dapat berupa IPS, nilai toefl, dan ekspresi penalaran logis dan analitis dalam bentuk lisan dan tulisan, serta (3) ketekunan mereka.

2. Faktor eksternal. Faktor ini erat kaitannya dengan kurikulum, metode pengajaran, materi linguistik, dan pustaka linguistik. Kurikulum yang dimaksud di sini berhubungan dengan proporsi mata kuliah linguistik yang disediakan dalam sebuah kurikulum. Sebagaimana yang disampaikan mahasiswa dalam menjawab kuesioner, bahwa salah satu alasan yang membuat mereka memilih bidang linguistik sebagai tugas akhir mereka, kerena mata kuliah linguistik memang lebih banyak jumlahnya dibanding bidang lain. Artinya, mereka lebih banyak terpapar dengan materi lingusitik setiap semester dari pada materi susastra dan budaya. Mau tidak mau, menurut mereka, secara psikologis, informasi tentang kajian linguistik lebih banyak mereka peroleh dari pada kajian susastra dan budaya. Konsekuensinya, 
mereka akan memilih bidang linguistik sebagai topik skripsi mereka.

Berdasarkan dua faktor tersebut, beberapa hal yang dapat dilakukan untuk meminimalisir kendala pembelajaran linguistik Arab adalah sebagai berikut:

1. Faktor Internal.

a. Prodi Sastra Arab FS UAI harus mendapatkan input mahasiswa dengan kemampuan yang memadai untuk menjadi mahasiswa S1. Mengapa demikian? Menjadi mahasiswa S1 berbeda dengan mahasiswa pada level di bawahnya, misalnya D3, D2, dan lainlain. Ada kapasitas khusus yang harus dimiliki seseorang yang menjadi mahasiswa S1, yaitu penalaran logis, kerangka berpikir sistematis, dan analisis ilmiah dalam memandang sesuatu. Hal tersebut dapat diindikasikan dan diukur melalui tes potensial akademik (TPA). Itu artinya, passing grade input mahasiswa yang masuk ke prodi Sastra Arab UAI harus ditingkatkan. Dengan kemampuan akademik yang memadai, mahasiswa dapat menghimpun beragam pustaka, membacanya, meninjau pustaka itu dan menuliskannya menjadi sebuah tulisan telaah pustaka yang kronologis dan sistematis.

b. Meningkatkan kemampuan bahasa Inggris mahasiswa. Dengan kemampuan bahasa Inggris yang memadai, mahasiswa tidak akan mengalami kesulitan yang berarti ketika disodori artikel berbahasa Inggris. Mereka dapat mempresentasikan isi artikel dengan pemahaman yang baik terhadap isi tersebut.

c. Motivasi dan ketekunan dapat dimunculkan melalui dukungan dan latihan. Mereka yang tidak memiliki motivasi yang baik ketika mempelajari sesuatu, biasanya hasilnya tidak akan baik pula. Dalam konteks ini, diperlukan support dari orang tua, dosen, dan orangorang yang ia cintai. Mereka, dalam waktu yang bersamaan memberikan gambaran yang baik bahwa mempelajari linguistik Arab itu bukanlah hal yang siasia. Bahkan sebaliknya, banyak sekali yang dapat dijadikan ladang untuk berkarya di bidang linguistik di masa depan mereka. Gambaran-gambaran itu yang setidaknya membuat mereka termotivasi untuk bersemangat belajar linguistik Arab, yang pada akhirnya mereka akan menjadi tekun.

2. Faktor eksternal

a. Kurikulum prodi Sastra Arab yang berlaku pada saat itu adalah kurikulum 2010. Muatan linguistiknya memang lebih banyak dibandingkan muatan susastra dan budaya. Ini menjadi bahan evaluasi yang sangat baik unruk perubahan kurikulum di masa yang akan datang. Pada tahun 2013, kurikulum yang mengakomodasi muatan susastra sedikit lebih banyak dibandingkan kurikulum 2010. Mahasiswa yang tertarik meneliti bidang susastra sudah mulai terakomodasi. Namun, dosen yang mengampu bidang susastra lebih sering diambil dari luar UAI. Ini juga menjadi tantangan untuk pemberlakuan kurikulum 2017. Saat ini, rekrutmen dosen di prodi Sastra Arab dikhususkan pada mereka yang menekuni bidang susastra dan budaya.

b. Metode mengajar para dosen linguistik di prodi Arab memang variatif, bergantung kepada individu pengajar. Namun, sejauh ini yang dianggap menjadi kendala bagi mahasiswa adalah metode ceramah yang mendominasi jam kuliah di kelas. Untuk mengatasi hal tersebut, para dosen telah diinformasikan perihal ketidaknyamanan mahasiswa jika penyampaian materi kuliah hanya dengan metode ceramah.

c. Materi linguistik yang dianggap sulit dan pustaka linguistik yang juga dianggap sulit untuk memahaminya adalah sesuatu yang sifatnya relatif. Dalam mengatasi hal yang satu ini, dosen harus lebih banyak memberikan tugas membaca pustaka dan meminta mahasiswa mempresentasikannya di kelas. Dengan situasi yang demikian, mahasiswa "dipaksa" membaca, sehingga pengetahuan mereka bertambah tentang linguistik Arab

\section{SIMPULAN DAN SARAN}

\section{Simpulan}

Lingusitik adalah "alat" yang dapat dipakai untuk mengkaji bidang ilmu lainnya yang 
berkaitan dengan bahasa. Karena itulah mata kuliah bidang lingusitik di prodi bahasa dan sastra menjadi keharusan. Namun, proses pembelajaran itu sendiri mengalami beberapa kendala. Kendala tersebut sangat signifikan mempengaruhi proses pencerapan materi linguistik dari awal kuliah hingga mahasiswa menulis tugas akhir. Ironisnya, linguisik yang dianggap sulit materinya tersebut dijadikan bidang kajian mereka dalam menulis tugas akhir. Setelah dilakukan anallisis terhadap data dari responden, ditemukan beberapa hal berikut yang menjadi penghambat, yaitu

\section{1. faktor internal}

Bagian ini mencakupi (1) motivasi mahasiswa, (2) kompetensi akademik mereka yang wujudnya dapat berupa IPS, nilai toefl, dan ekspresi penalaran logis dan analitis dalam bentuk lisan dan tulisan, serta (3) ketekunan mereka.

\section{2. faktor eksternal}

Faktor ini erat kaitannya dengan kurikulum, metode pengajaran, materi linguistik, dan pustaka linguistik

\section{Saran}

Kajian ini akan menjadi lengkap dengan menambah jumlah responden, dan melakukan observasi pada kelas tiap-tiap dosen linguistik enambah jumlah responden, dan melakukan observasi pada kelas tiap-tiap dosen linguistik. Observasi ke dalam kelas linguistik akan menambah informasi terkait metode pengajaran dosen, serta respon mahasiswa ketika menyimak dosen mengajar.

\section{DAFTAR PUSTAKA}

[1] Basuki, Sunaryono K.S. 1999. Pengajaran dan Pemerolehan Bahasa untuk Orang Asing. www. Iaif.edu/bipa/July 1999

[2] Fahrurrozi, Aziz. 2014. "Pembelajaran Bahasa Arab: Problematika dan Solusinya ", dalam Arabiyat, Jurnal Pendidikan Bahasa Arab dan Kebahasaaraban. Jurnal.uinjkt.ac.id

[3] Malone, D. 2002. Theoris and Research of Second Language Acquisition. MLE WS Bangkok

[4] Hidayat, Nandang Sarif. 2012. "Problematika Pembelajaran Bahasa Arab", dalam An Nida, Jurnal Pemikiran Islam Vol.37 No.1 Jan-Juni 2012

[5] Hurford, James R. 1990. Nativist and Functional Explanations in Language Acquaisition. University of Edinburgh.

[6] Kushartanti, Untung Yuwono, Multamia RMT Lauder (Penyunting). 2007. Pesona Bahasa, Langkah Awal Memahami Linguistik. Jakarta: Gramedia

[7] Shafa, S. 2012. Teori Pemerolehan Bahasa dan Implikasinya dalam Pembelajaran.

Journal.iain_samarinda.ac.id 